\title{
Production and performance of sugarcane seeds (caryopses) from different hybridizations involving RB92579
}

\author{
CARLOS A. DINIZ, VILMA M. FERREIRA, CLÍSSIA B. DA SILVA, GERALDO V.S. \\ BARBOSA, JOÃO C. DE ARAÚJO NETO and JOÃO M. DOS SANTOS \\ Universidade Federal de Alagoas, Centro de Ciências Agrárias, BR 104 Norte, Km 85, 57100-000 Rio Largo, AL, Brazil
}

Manuscript received on May 2, 2017; accepted for publication on October 31, 2017

\begin{abstract}
A major challenge in sugarcane breeding program is the obtaining of enough number of seeds (caryopses) for the development of new improved cultivars. Genotypes differ in their function as pollen recipient and pollen donor, which also affect the seed performance. Thus, the aim of this study was to verify the production and performance of sugarcane seeds from different hybridizations involving RB92579 as pollen recipient and pollen donor. Twelve bi-parental crossings were carried out involving RB92579 and other different genotypes randomly chosen. Seed production potential was evaluated by percentage of fertile spikelets and caryopsis fresh weight. The seed physiological potential was determined by evaluating germination and vigor (index of germination rate, number of normal seedlings per gram of fuzz, and seedling dry weight). The results showed better performance for RB92579 as pollen donor for all characteristics studied. Therefore, RB92579 sugarcane cultivar should be used as pollen donor during hybridizations, condition that permits a greater production and physiological performance of seeds for the sugarcane breeding programs.
\end{abstract}

Key words: fertile spikelets, pollen donor, pollen recipient, Saccharum spp., sugarcane breeding.

\section{INTRODUCTION}

Sugarcane (Saccharum spp.) is the world's most important sugar-producing crop. Global interest in sugarcanehas also increased because of its economic impact on the sustainable energy production (Hoang et al. 2015). Sugarcane breeding programs have been working extensively to the development of hybrid seeds (caryopses) with desirable agroindustrial traits (Cheavegatti-Gianotto et al. 2011). The Northeastern region of Brazil is a traditional

Correspondence to: Carlos Assis Diniz

E-mail: carlos_assispc@hotmail.com producer of sugarcane, and RB92579 cultivar is one of the major cultivar used in hybridization of sugarcane in this region. RB92579 is characterized by high productivity and adaptability to adverse environmental conditions that can be inherited by their descendants (Daros et al. 2015).

A major challenge in sugarcane breeding program is the obtaining of enough number of seeds for the development of new improved cultivars (Heinz and Tew 1987). Genotypes differ widely in their role as maternal parent (pollen recipient) or paternal parent (pollen donor). This can negatively affect seed production and later performance 
(McIntyre and Jackson 2001). Accordingly, it is particularly important to determine the responses of each cultivar as pollen recipient and pollen donor during hybridization. The incorrect use of a genotype as pollen donor, for instance, can cause molecular or physiological changes that may affect seed quality and production potential. Therefore, differences between inflorescence condition as pollen recipient and pollen donor should always be considered during the hybrid seed production.

Moreover, since the seedling performance is directly dependent on seed vigor (Silva et al. 2012), higher seed vigor plays an important role during breeding programs because high-vigor seed lots are expected to produce strong seedlings with ability to express their real genetic traits. In addition, the use of high-vigor seed lots assures more uniform stand of plants in the field (Marcos-Filho 2015), which can also contribute more efficiently to the selection of agronomically desirable genotypes for the breeding programs.

Thus, this research aimed to study the production and performance of sugarcane seeds from different hybridizations involving RB92579 as pollen recipient and pollen donor.

\section{MATERIALS AND METHODS}

Crossing experiments of sugarcane cultivars were conducted at the Sugarcane Flowering and Crossing Station Serra do Ouro, located in Murici, AL, Brazil ( $9^{\circ} 13^{\prime} \mathrm{S}, 35^{\circ} 50^{\prime} \mathrm{W}, 450 \mathrm{~m}$ asl) from May to June 2014. Evaluations were carried out at the Plant Propagation Laboratory and in a greenhouse, located at the Center of Agricultural Sciences, Federal University of Alagoas, Rio Largo, AL, Brazil from October 2014 to April 2015.

\section{CROSSINGS AND SEED MATERIAL}

Twelve bi-parental crossings were carried out between RB92579 and six different cultivars: H64-1881, RB855551, RB92606, RB925211,
RB981809 and VAT90-212. The cultivars were randomly chosen. The study was performed using two hybridization conditions: 1) RB92579 as pollen recipient; 2) RB92579 as pollen donor.

The hybridization process was conducted using the method described by Barbosa et al. (2002). After seed processing, the seeds were kept in multi-layered Kraft paper containers and stored at $20{ }^{\circ} \mathrm{C}$ and $50 \%$ relative air humidity during the experimental period.

\section{SEED PRODUCTION POTENTIAL}

Seed production potential was evaluated for the percentage of fertile spikelets and caryopsis fresh weight. The percentage of fertile spikelets was determined with three replicates of $0.25 \mathrm{~g}$ 'fuzz' (glumes, lemma, palea and caryopses), which was evaluated manually for the absence or presence of caryopsis. For caryopsis fresh weight, three replicates of caryopses were used for each crossing. All the caryopses were weighed, and the results were expressed as individual fresh weight of caryopsis for each crossing.

\section{SEED PHYSIOLOGICAL POTENTIAL}

Seed physiological potential was evaluated by germination and vigor tests (index of germination rate - GR, number of normal seedlings per gram of fuzz, and seedling dry weight). Seed germination tests were conducted with three replicates of 100 spikelets per crossing. Spikelets were distributed on paper towel moistened with water equivalent to 2.5 times the paper weight, and then placed at bottom of plastic boxes $(11.0 \times 11.0 \times 3.5 \mathrm{~cm})$ under alternating temperature of $20-30{ }^{\circ} \mathrm{C}$ and continuous light (Caieiro et al. 2010). The number of normal seedlings was recorded daily to obtain index of germination rate (Maguire 1962). Germination percentage was calculated at 10 days after sowing (Silva et al. 2010); results were expressed as a percentage of normal seedlings (Brasil 2009). 
For seedling emergence, three replicates with $1.0 \mathrm{~g}$ of fuzz were placed on a mix of black soil, coconut fiber and filter cake $(2: 1: 1)$ in plastic boxes $(40 \times 30 \times 15 \mathrm{~cm})$ arranged in a greenhouse. A micro-sprinkler irrigation system was applied to moisten substrate. The boxes were covered with transparent plastic sheet to avoid the water loss. Evaluations were made 21 days after sowing and the results expressed as number of emerged seedlings per gram of fuzz.

Twenty one days after seedling emergence, seedlings were transferred to plastic tubes. At 60 days after sowing, the third tube of each experimental parcel was selected to determine the seedling dry weight. For this, seedlings were placed in kraft paper bags and kept in oven with forced air circulation at $65^{\circ} \mathrm{C}$ for 72 hours.

\section{EXPERIMENTAL DESIGN AND STATISTICAL ANALYSIS}

Data were submitted to analysis of variance using a model linear hierarchical classification (Montgomery 2001). In each RB92579 condition, the parents means were compared using ScottKnott test $(p \leq 0.05)$.

\section{RESULTS AND DISCUSSION}

The seed production and physiological potential (Table I) were statistically different between crossings involving RB92579 as pollen recipient and pollen donor. As pollen donor, RB92579 showed higher performance compared to its pollen recipient condition.

Overall greater production of fertile spikelets (Table II) was verified during hybridization between RB92579 (pollen donor) and RB925211 (pollen recipient) with $50.2 \%$ of fertile spikelets, whereas RB981809 (pollen recipient) showed the worst performance with $6.0 \%$ of fertile spikelets.

On the other hand, although hybridization between RB92579 (pollen donor) and RB981809
TABLE I

Percentage of fertile spikelets (FS), caryopsis fresh weight (CFW), germination (G), index of germination rate (GR), number of normal seedlings per gram of fuzz (NS), and seedling dry weight (SDW) from hybridizations involving RB92579 sugarcane cultivar as pollen recipient and pollen donor.

\begin{tabular}{ccc}
\hline \multirow{2}{*}{ Characteristic* $^{*}$} & \multicolumn{2}{c}{ RB92579 condition } \\
\cline { 2 - 3 } & Pollen recipient & Pollen donor \\
\hline FS (\%) & $6.2 \mathrm{~b}$ & $27.5 \mathrm{a}$ \\
CFW (mg) & $0.15 \mathrm{~b}$ & $0.37 \mathrm{a}$ \\
G (\%) & $5.2 \mathrm{~b}$ & $17.2 \mathrm{a}$ \\
GR & $1.4 \mathrm{~b}$ & $4.6 \mathrm{a}$ \\
NS & $12 \mathrm{~b}$ & $110 \mathrm{a}$ \\
SDW $(\mathrm{mg})$ & $364.9 \mathrm{~b}$ & $710.2 \mathrm{a}$ \\
\hline
\end{tabular}

*Comparison of means within each row (F test, $\mathrm{p} \leq 0.05$ ).

(pollen recipient) has shown lower percentage of fertile spikelets, in the opposite condition, that is, RB92579 as pollen recipient and RB981809 as pollen donor, RB981809 showed the best performance (11.0\%); RB925211 showed the worst fertile spikelets values $(1.6 \%)$.

In this research, the highest fertility of sugarcane $(50.2 \%)$ was relatively low compared to other grasses (Fairey 1993). Pierre et al. (2015) also found low fertility in other sugarcane cultivars with an average of $31.8 \%$. Previous studies with RB92579 demonstrated that the fertility values did not exceed 25\% (Cabral et al. 2011). According to Creste et al. (2010), sugarcane genotypes have a high level of heterozygosity that results in marked genetic variability among progenitors and can reduce seed production.

RB92579 as pollen donor showed higher caryopsis fresh weight (Table II) compared to the pollen recipient condition, especially during hybridization involving RB855511 cultivar, which showed the highest germination percentage (Table II). The seed germination percentage (Table II) from crossings with RB92579 as pollen donor varied between 4 and $37 \%$. On the other hand, the results indicated lower performance for RB92579 
TABLE II

Percentage of fertile spikelets (FS), caryopsis fresh weight (CFW), germination (G), index of germination rate (GR), number of normal seedlings per gram of fuzz (NS), and seedling dry weight (SDW) from different hybridizations among RB92579 (pollen recipient or pollen donor) and other six sugarcane cultivars.

\begin{tabular}{|c|c|c|c|c|c|c|c|}
\hline \multirow{2}{*}{$\begin{array}{l}\text { RB92579 } \\
\text { condition }\end{array}$} & \multirow{2}{*}{ Parent } & \multicolumn{6}{|c|}{ Characteristic* } \\
\hline & & FS (\%) & CFW (mg) & G (\%) & GR & NS & SDW (mg) \\
\hline \multirow{6}{*}{ Pollen recipient } & H64-1881 & $6.6 \mathrm{~b}$ & $0.16 \mathrm{~b}$ & $8 \mathrm{a}$ & $2.1 \mathrm{a}$ & $35 \mathrm{a}$ & $397.4 \mathrm{a}$ \\
\hline & RB855551 & $7.2 \mathrm{~b}$ & $0.15 \mathrm{~b}$ & $5 \mathrm{a}$ & $1.3 \mathrm{a}$ & $8 \mathrm{a}$ & $273.1 \mathrm{a}$ \\
\hline & RB92606 & $1.6 \mathrm{e}$ & $0.10 \mathrm{c}$ & $2 b$ & $0.5 \mathrm{~b}$ & $2 \mathrm{a}$ & 199.7 a \\
\hline & RB925211 & $6.6 \mathrm{~b}$ & $0.15 \mathrm{~b}$ & $4 \mathrm{a}$ & $1.1 \mathrm{~b}$ & $6 \mathrm{a}$ & $266.6 \mathrm{a}$ \\
\hline & RB981809 & $11.0 \mathrm{a}$ & $0.14 \mathrm{~b}$ & $6 \mathrm{a}$ & $1.6 \mathrm{a}$ & $10 \mathrm{a}$ & $427.4 \mathrm{a}$ \\
\hline & VAT90-212 & $4.1 \mathrm{c}$ & $0.21 \mathrm{a}$ & $5 \mathrm{a}$ & $1.5 \mathrm{a}$ & $9 \mathrm{a}$ & $444.0 \mathrm{a}$ \\
\hline \multirow{7}{*}{ Pollen donor } & H64-1881 & $14.2 \mathrm{~d}$ & $0.23 \mathrm{~d}$ & $19 \mathrm{~b}$ & $4.4 \mathrm{~b}$ & $134 \mathrm{~b}$ & $751.3 \mathrm{~b}$ \\
\hline & RB855551 & $42.8 \mathrm{~b}$ & $0.57 \mathrm{a}$ & $37 \mathrm{a}$ & $11.4 \mathrm{a}$ & $206 \mathrm{a}$ & $603.9 \mathrm{~b}$ \\
\hline & RB92606 & $26.4 \mathrm{c}$ & $0.39 \mathrm{c}$ & $4 \mathrm{~d}$ & $1.2 \mathrm{~d}$ & $37 \mathrm{c}$ & $647.5 \mathrm{~b}$ \\
\hline & RB925211 & $50.2 \mathrm{a}$ & $0.52 \mathrm{~b}$ & $19 \mathrm{~b}$ & $4.1 \mathrm{~b}$ & $131 \mathrm{~b}$ & $1.085 .3 \mathrm{a}$ \\
\hline & RB981809 & $6.0 \mathrm{e}$ & $0.12 \mathrm{e}$ & $8 \mathrm{c}$ & $2.0 \mathrm{c}$ & $19 \mathrm{c}$ & $538.3 \mathrm{~b}$ \\
\hline & VAT90-212 & $25.5 \mathrm{c}$ & $0.40 \mathrm{c}$ & $14 \mathrm{c}$ & $4.2 \mathrm{~b}$ & $131 \mathrm{~b}$ & $899.4 \mathrm{a}$ \\
\hline & C.V. (\%) & 12.65 & 8.64 & 19.64 & 15.48 & 41.03 & 22.68 \\
\hline
\end{tabular}

*Any two means followed the different letters within a column indicate statistically significant difference (Scott-Knott test, $\mathrm{p} \leq$ $0.05)$.

as pollen recipient in which case the highest germination percentage was $8 \%$.

Since caryopsis fresh weight of RB92579 as pollen recipient was lower than pollen donor condition, it seems reasonable to assume that there were no enough stored reserves in the endosperm for providing nutrients to support early seedling growth with RB92579 as pollen recipient. Moreover, the endosperm contains hydrolysis enzymes to the starchy endosperm, and the embryo utilizes sugars released by starch degradation for its growth (Yan et al. 2014).

The index of germination rate (Table II) involving RB92579 as pollen donor and RB855511 as pollen recipient was also higher than other genotypes reaching values of 11.4; for RB92579 crossed with other genotypes the index of germination rate varied from 1.2 to 4.4 , and RB92579 as pollen recipient the highest index value was 2.1 .
For sugarcane breeding, genotypes are selected against flowering, and the energy produced is mainly used to increase crop yield (Berding and Hurney 2005). This can negatively affect fertility of flowers, seed production and performance (Olaoye and Adams 1996, Cabral et al. 2011, Pierre et al. 2015).

The number of normal seedling per gram of fuzz (Table II) was higher during hybridization between RB92579 (pollen donor) and RB855511 (pollen recipient). For seedling dry weight (Table II), results indicated that the best performance was exhibited by RB925211 (pollen recipient).

Depending on the genotype, sugarcane hybridization showed different performance, however, the best results were obtained by RB92579 as pollen donor. This can also be verified by a digital image of seedling roots of different hybridizations (Figure 1); seedlings from hybridizations involving RB92579 as pollen donor 


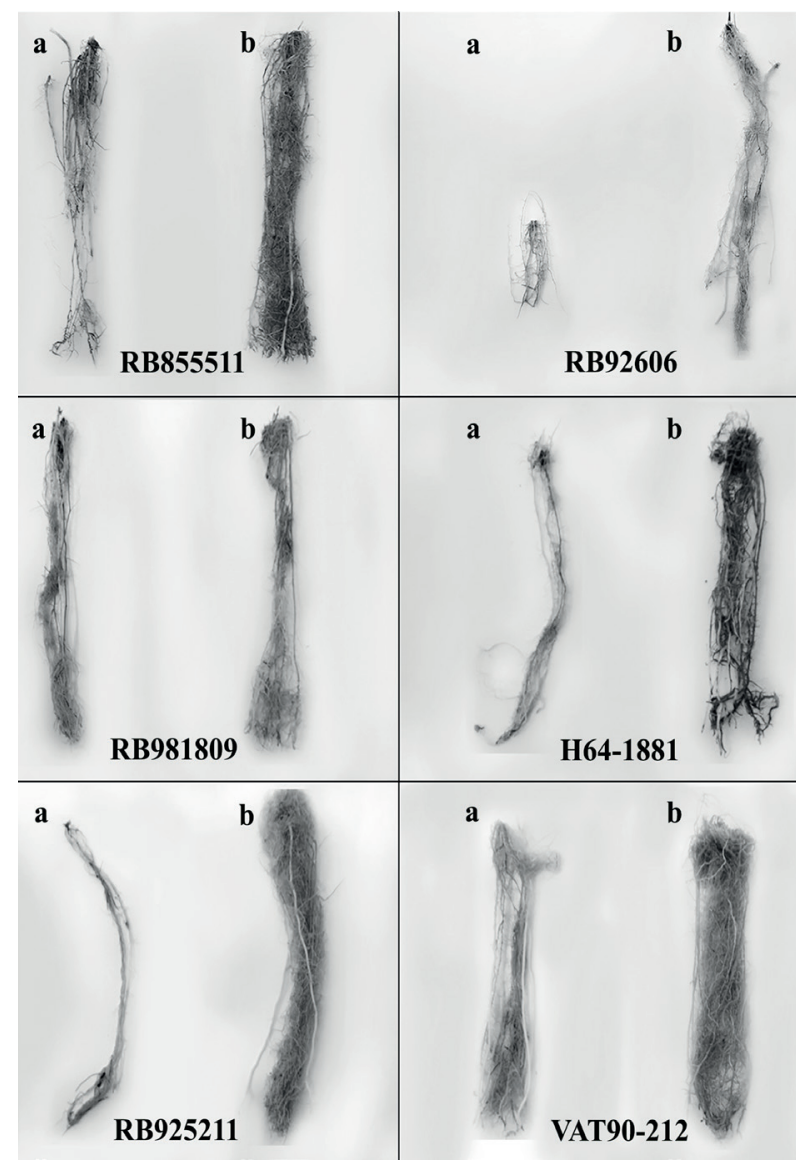

Figure 1 - Digital images of sugarcane seedling roots from different hybridizations among RB92579 (as pollen recipient - $\mathbf{a}$ and pollen donor $-\mathbf{b}$ ) and other six sugarcane cultivars.

exhibited a more vigorous root growth compared to those produced from RB92579 as pollen recipient.

Thus, higher seed vigor such as those that are the result of crossings with RB92579 as pollen donor, produced strong seedlings with more roots compared to those from lower seed vigor (RB92579 as pollen recipient). In general, a reduced root growth can limit the contact of roots to the soil in which there were grown, and plants can show difficult to establish in the field during transplant. In addition, a reduced root length also affects the water absorption capacity and consequently the crop yield. In this research, if seedlings produced from crossings involving RB92579 as pollen recipient had been transplanted to the field, probably they would have more difficulties to establish in the soil as well as reduced yield potential.

Therefore, seeds raised from RB92579 as pollen recipient showed clearly lower performance compared to its performance as pollen donor, with low capacity for female parent. Since the seedlings are obtained from sugarcane seeds during the first selection stage of a sugarcane breeding, such information is essential because can permit a more efficient selection of superior cultivars and allow them to express their real genetic potential; in fact, the higher the seed quality, the faster the seedling emergence, with capacity to tolerate better the adverse environmental conditions in the field (Marcos-Filho 2015).

Lower performance of RB92579 as pollen recipient can in part be explained by fertility problems because of problems with the ovule development, pollen-pistil incompatibility, maternal factors such as the position of the inflorescence on the mother plant or the position of the seeds along the inflorescence, or embryos fail to develop successfully (Gutterman et al. 2000, Alarmelu and Shanthi 2011, Schroeder et al. 2012, Melloni et al. 2013). Thus, although sugarcane flowers are hermaphrodites, RB92579 showed better performance as pollen donor, with predominant male reproductive function, possibly due to the greater degree of anther opening and higher pollen fertility.

In conclusion, for breeding programs the RB92579 sugarcane cultivar should always be used as pollen donor during hybridizations, condition that permit a greater seed production and performance.

\section{REFERENCES}

ALARMELU S AND SHANTHI RM. 2011. Incompatibility studies in sugarcane (Saccharum spp.). Indian J Genet Plant Breed 71: 43-48.

BARBOSA GVS, CRUZ MM, SOARES L, ROCHA AMC, RIBEIRO CAG, SOUSA AJR, FERREIRA JLC, 
BARRETO EJS, SILVA WCM AND SANTOS AVP. 2002. A brief report on sugarcane breeding program in Alagoas, Brazil. Crop Breed Appl Biotechnol 2: 613-616.

BERDING N AND HURNEY AP. 2005. Flowering and lodging, physiological-based traits affecting cane and sugar yield: What do we know of their control mechanisms and how do we manage them? Field Crops Res 92: 261275.

BRASIL. 2009. Ministério da Agricultura, Pecuária e Abastecimento - Secretaria de Defesa Agropecuária. Regras para Análise de Sementes, Brasília: Mapa/ACS, $399 \mathrm{p}$.

CABRAL FF, SILVA CB, FERREIRA VM, ARAÚJO NETO JC AND BARBOSA GVS. 2011. Fertilidade de cruzamentos, potencial físiológico e armazenamento de sementes de cana-de-açúcar. Pesqui Apl Agrotec 4: 66-82.

CAIEIRO JT, PANOBIANCO M, BESPALHOK FILHO JC AND OHLSON OC. 2010. Physical purity and germination of sugarcane seeds (caryopses) (Saccharum spp.). Rev Bras Sementes 32: 140-145.

CHEAVEGATTI-GIANOTTO A ET AL. 2011. Sugarcane (Saccharum X officinarum): A reference study for the regulation of genetically modified cultivars in Brazil. Trop Plant Biol 4: 62-89.

CRESTE S, ACCORONI KAG, PINTO LR, VENCOVSKY R, GIMENES MA, XAVIER MA AND LANDELL MGA. 2010. Genetic variability among sugarcane genotypes based on polymorphisms in sucrose metabolism and drought tolerance genes. Euphytica 172: 435-446.

DAROS E, OLIVEIRA RA AND BARBOSA GVS. 2015. 45 anos de variedades RB de cana-de-açúcar: 25 anos de RIDESA, $1^{\text {a }}$ ed., Curitiba: Graciosa, 156 p.

FAIREY DT. 1993. Pollination and seed set in herbage species: a review of limiting factors. J Appl Seed Prod 11: 6-9.

GUTTERMAN Y. 2000. Maternal effects on seeds during development. In: Fenner M (Ed), Seeds: The ecology of regeneration in plant communities, $2^{\text {nd }}$ ed., Wallingford: CAB International, Wallingford, UK, p. 59-84.

HEINZ DJ AND TEW TL. 1987. Hybridization procedures. In: Heinz DJ (Ed), Sugarcane Improvement Through Breeding, Amsterdam: Elsevier, p. 313-342.
HOANG NV, FURTADO A, BOTHA FC, SIMMONS BA AND HENRY RJ. 2015. Potential for genetic improvement of sugarcane as a source of biomass for biofuels. Front Bioeng Biotechnol 3: 1-15.

MAGUIRE JD. 1962. Speed of germination: aid in selection and evaluation for seedling emergence and vigor. Crop Sci 2: $176-177$.

MARCOS-FILHO J. 2015. Seed vigor testing: an overview of the past, present and future perspective. Sci Agric 2: 363-374.

MCINTYRE CL AND JACKSON P. 2001. A. Low level of selfing found in a sample of crossings in Australian sugarcane breeding programs. Euphytica 117: 245-249.

MELLONI MLG, SCARPARI MS, MENDONÇA JR, PERECIN D, LANDELL MGA AND PINTO LR. 2013. Comparison of two staining methods for pollen viability studies in sugarcane. Sugar Tech 15: 103-107.

MONTGOMERY DC. 2001. Design and analysis of experiments, $5^{\text {th }}$ ed., New York: J Wiley \& Sons, $682 \mathrm{p}$.

OLAOYE G AND ADAMS OM. 1996. Effects of different growth media on germination and perform of sugarcane fuzz (seeds). Biosci Res Commun 8: 117-122.

PIERRE JS, PERROUX J, WHAN A, RAE AL AND BONNETT GD. 2015. Poor fertility, short longevity, and low abundance in the soil seed bank limit volunteer sugarcane from seed. Front Bioeng Biotechnol 3: 1-11.

SCHROEDER J, BURKE T, MANNARELLI ME, DAWSON DA AND NAKAGAWA S. 2012. Maternal effects and heritability of annual productivity. J Evol Biol 25: 149156.

SILVA CB, LOPES MM, MARCOS-FILHO J AND VIEIRA RD. 2012. Automated system of seedling image analysis (SVIS) and electrical conductivity to assess sun hemp seed vigor. Rev Bras Sementes 34: 55-60.

SILVA MA, CAPUTO MM, PERECIN D AND BRESSIANI JA. 2010. Comparação de ambientes na germinação de cariopses de cana-de-açúcar. Cienc Agrotec 34: 16041609.

YAN D, DUERMEYER L, LEOVEANU C AND NAMBARA E. 2014. The functions of the endosperm during seed germination. Plant Cell Physiol 55: 1521-1533. 